\title{
Species pool versus site limitations of macrophytes in urban waters
}

\author{
K. Vermonden • R. S. E. W. Leuven • G. van der Velde • A. J. Hendriks • \\ M. M. van Katwijk • J. G. M. Roelofs • E. C. H. E. T. Lucassen • \\ O. Pedersen $\cdot$ K. Sand-Jensen
}

Received: 22 October 2009/Accepted: 12 March 2010/Published online: 1 April 2010

(C) The Author(s) 2010. This article is published with open access at Springerlink.com

\begin{abstract}
Biodiversity in urban areas is affected by a multitude of stressors. In addition to physico-chemical stress factors, the native regional species pool can be greatly reduced in highly urbanized landscapes due to area loss and fragmentation. In this study, we investigated how macrophyte composition and diversity in urban water systems are limited by the regional species pool and local environmental conditions. Canonical correspondence analysis of the macrophyte species composition revealed
\end{abstract}

K. Vermonden · R. S. E. W. Leuven ( $₫)$.

A. J. Hendriks - M. M. van Katwijk

Department of Environmental Science, Institute for Water and Wetland Research,

Radboud University Nijmegen, Heyendaalseweg 135,

6525 AJ Nijmegen, The Netherlands

e-mail: r.leuven@science.ru.nl

K. Vermonden · O. Pedersen · K. Sand-Jensen

Freshwater Biological Laboratory, University of Copenhagen,

Helsingørsgade 51, 3400 Hillerød, Denmark

G. van der Velde

Department of Animal Ecology and Ecophysiology,

Institute for Water and Wetland Research,

Radboud University Nijmegen, Heyendaalseweg 135,

6525 AJ Nijmegen, The Netherlands

G. van der Velde

Netherlands Centre for Biodiversity Naturalis,

P.O. Box 9517, 2300 RA Leiden, The Netherlands

J. G. M. Roelofs

Department of Aquatic Ecology and Environmental Biology, Institute for Water and Wetland Research,

Radboud University Nijmegen, Heyendaalseweg 135,

6525 AJ Nijmegen, The Netherlands

J. G. M. Roelofs - E. C. H. E. T. Lucassen

B-WARE Research Centre, Radboud University Nijmegen,

Heyendaalseweg 135, 6525 AJ Nijmegen, The Netherlands that urban and semi-natural water systems differed and differences could be related to local abiotic variables such as $\mathrm{pH}$ and iron concentrations. Macrophytes in the seminatural area were typical for slightly acid and oligotrophic conditions. In urban water systems, exotic species characteristic of eutrophic conditions were present. In the seminatural areas, the number of macrophyte species exceeded the number of species expected from species-area relationships of artificial water bodies in rural areas. In urban areas, the number of macrophyte species was similar to artificial water systems in rural areas. Macrophyte species present in the study areas also were generally found within 20-30 km distance to the study area. Macrophyte species composition in urban water systems and semi-natural water systems appeared to be influenced by the regional species pool within approximately $30 \mathrm{~km}$ of the locations. Nevertheless, site limitation ultimately determined the local macrophyte species composition and diversity in urban water systems and in semi-natural water systems.

Keywords Biodiversity - Eutrophication · Local and regional processes - Macrophytes . Species-area relationships · Urban water systems . Vegetation

\section{Introduction}

Traditionally, patterns of species composition and diversity have been linked to small-scale processes such as geomorphology, hydrochemistry, competition and disturbance (Cornell and Lawton 1992). In the last two decades, processes at regional and historical scales, including longdistance dispersal, speciation and extinction, have been taken into account as well (Cornell and Lawton 1992; 
Zobel 1997; Ricklefs 2004). The local species pool often depends on the size and composition of the regional species pool (Caley and Schluter 1997; Zobel 1997; Partel and Zobel 1999).

Biodiversity in urban areas is affected by a multitude of stressors (Paul and Meyer 2001). In addition to physicochemical stress factors, the native regional species pool can be greatly reduced in highly urbanized landscapes due to area loss and fragmentation (Collinge 1996; Drayton and Primack 1996; McKinney 2005). Restoration of ecosystems within these landscapes often obtains poor results (Larson et al. 2001; Booth 2005; Suren and McMurtrie 2005).

The effects of urbanisation on macrophytes in water systems have not been studied extensively (Paul and Meyer 2001). Ranta and Toivonen (2008) found that aquatic macrophyte species composition had changed considerably in an increasingly urbanised Finnish lake area during the 20th century, but the number of species remained constant. The number of macrophyte species in Sydney streams was higher in urban systems than in non-urban systems, but the number of native species did not differ (King and Buckney 2000). Cheruvelil and Soranno (2008) found that the abundance of emergent and nymphaeid vegetation in Michigan lakes was negatively related to road density and urban land use. There is very little information on the limiting factors for aquatic macrophytes in urban areas.

In this study, we investigate how macrophyte composition and diversity in urban waters is related to local environmental conditions and if local macrophyte assemblages are also limited by the regional species pool. The towns of Arnhem and Nijmegen in the Netherlands were chosen as a case study on urban water systems. Multivariate analysis was used to relate macrophyte assemblages in urban and semi-natural water systems to environmental variables. We used a power function to relate local species diversity in urban and semi-natural water systems to the regional species diversity in surrounding rural areas. The species area relationship (SAR) can be used to predict the number of species (species richness) in a certain area (Evans et al. 1955; He and Legendre 1996), and test if specific areas are low in the number of species (Hamilton et al. 2009).

This study focussed on three research questions:

1. Does macrophyte species composition and richness in urban drainage systems differ from semi-natural and artificial water systems in surrounding rural areas and can these differences be related to environmental variables?

2. Does macrophyte species diversity in urban water systems and semi-natural water systems correspond to predicted species diversity using species-area relationships of artificial water systems in surrounding rural areas?
3. Is species composition in urban water systems and semi-natural water systems limited by the regional species pool and/or local environmental conditions?

\section{Methods}

Study area

The municipalities of Nijmegen and Arnhem are situated in the eastern part of the Netherlands along distributaries of the River Rhine (rivers Waal and Nederrijn, respectively) (Fig. 1a). The municipalities of Nijmegen and Arnhem have approximately 2,803 and 1,414 inhabitants per $\mathrm{km}^{2}$, respectively (Statistics Netherlands 2009). In the 1970s, urban water systems were designed in the polder areas of both cities to manage groundwater levels and to drain seepage and storm water into rivers (Vermonden et al. 2009a). Separate sanitary sewer systems were constructed in the study area to transport sewage (Vermonden et al. 2009b). Sewage is pumped directly to the sewage treatment plant and is not discharged into the urban drainage systems. Another pipe system was designed to convey storm water runoff directly to surface waters. The lotic water systems in the study are therefore only fed by stormwater runoff and upward seepage of groundwater. Approximately $4 \%$ of the surface area in these cities consists of watercourses that are connected via culverts. The water level is regulated via weirs in the main watercourses. Slow-flowing (current velocity on average 3-14 $\mathrm{cm} \mathrm{s}^{-1}$ ), permanent watercourses can vary from linear ditches to ponds, generally 5-40 m wide and up to $3 \mathrm{~m}$ deep. Water systems are mowed once or twice a year depending on vegetation development. Four sites in Nijmegen and 11 sites in Arnhem were dredged 13 years before monitoring took place. Land use is predominantly residential, with an impervious area of approximately $30 \%$ (roads, buildings, parking lots), and $66 \%$ is taken up by gardens, parks and other green areas (Vermonden et al. 2009a).

For this study, 30 water bodies in Nijmegen and 15 in Arnhem were selected and monitored in August-September 2007. Locations varied in morphology, water quality, and vegetation composition. Urban water systems were compared to similar water bodies in a semi-natural area in the immediate vicinity. Since natural water systems do not exist now in the Netherlands, semi-natural water systems in rural areas were used, and were located on the eolian sand area (Fig. 1b). Monitoring of semi-natural water systems was done in eight locations, $1-3 \mathrm{~km} \mathrm{SW}$ of Nijmegen in April 2009. Four locations were oligotrophic, slightly acidic ditches or ponds. The other four locations were ditches under the influence of upward seepage of 


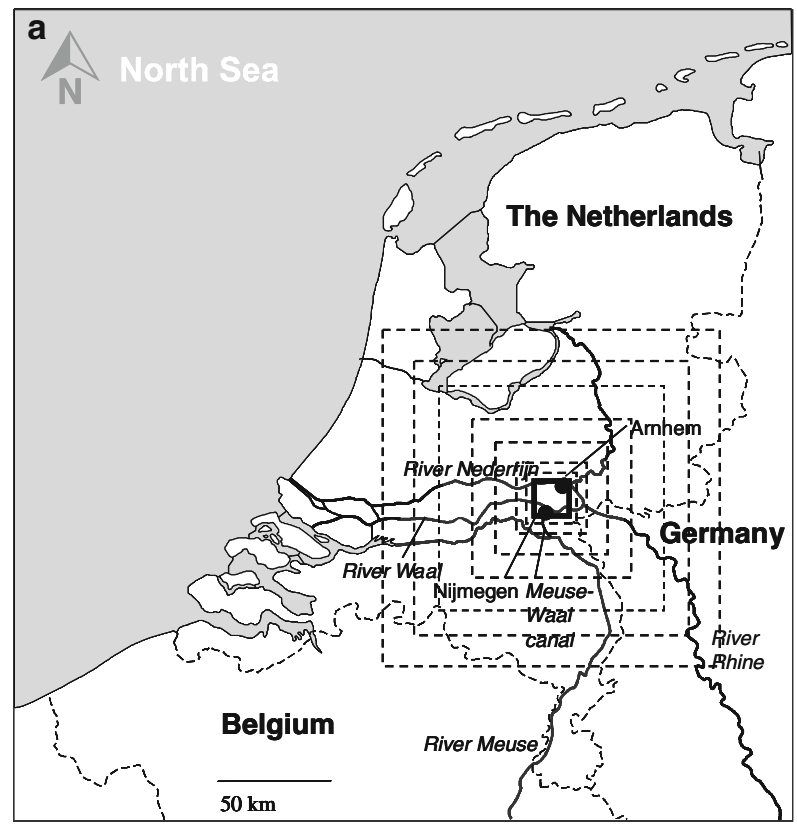

b

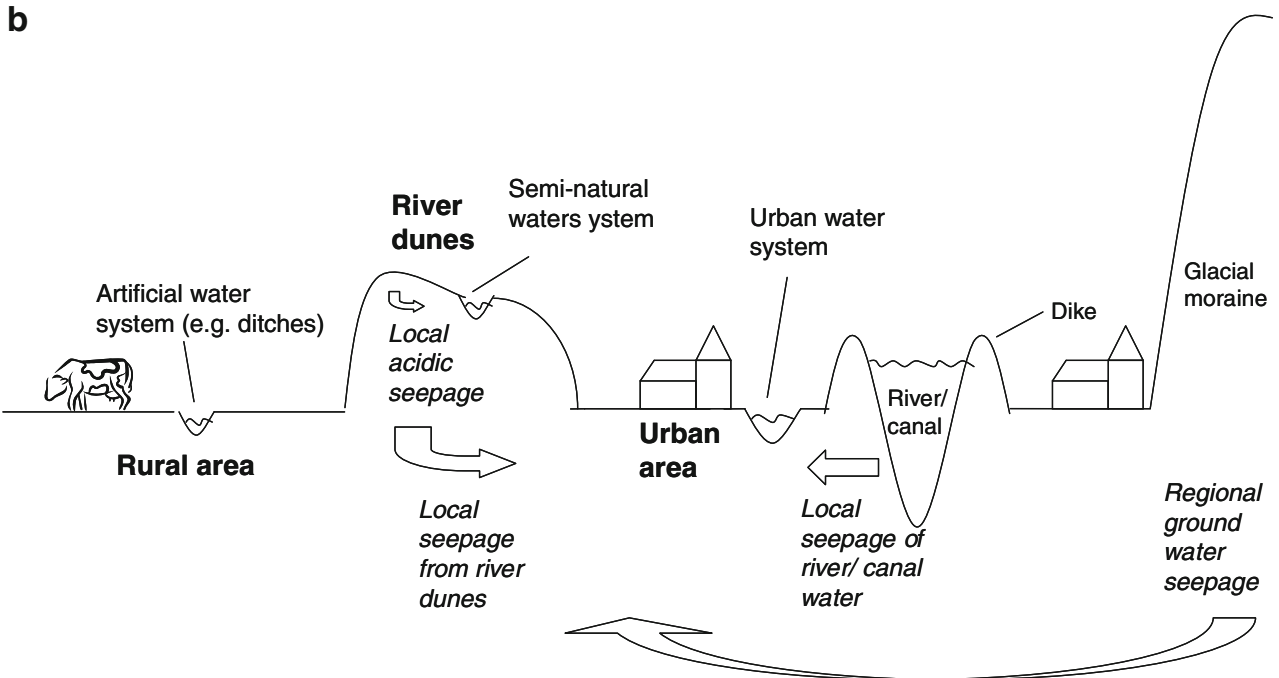

Fig. 1 Schematic overview of the study area with bold square indicating the surface area around Arnhem and Nijmegen and dashed squares indicating the surface areas used to calculate species-area

groundwater and therefore less acidic and somewhat enriched with nutrients. Sites were mowed once a year.

To determine the influence of the regional species pool on the local species pool (urban and semi-natural) in the study area, we used the national database of the Dutch waterboards (STOWA 2008). From this database we developed the regional database by selecting data on artificial water bodies at varying distances from the study area (Fig. 1a). The national database mostly included ditches (34\%), (small) lakes (26\%) and lotic water bodies such as small streams and rivulets (19\%), and the remaining $21 \%$ were rivers, softwater lakes, canals and springs (STOWA 2008). The sampling sites included in the national database relationships in rural areas (a). Main groundwater flows of the urban water systems, semi-natural water systems and artificial water systems in rural areas (b)

were mostly located in rural areas. Data in the national database were collected in the period 2000-2006.

\section{Macrophytes}

Macrophyte species composition was recorded on an abundance scale from 1 to 9 , corresponding to classes of the Tansley scale (Tansley 1946): sporadic, rare, occasional, locally frequent, frequent, locally abundant, abundant, codominant, dominant, respectively. Hydrophytes and helophytes were monitored for a stretch of approximately 20 metres along each sampling location. Hydrophytes were defined as aquatic plants living in or on the surface water 
(Antoine et al. 2004). Hydrophytes were observed in the surface water within two to three metres of the bank. Helophytes were rooted in the wet soil of the banks or in the sediment just below the surface water with shoots in the air (Antoine et al. 2004). Marsh and other plants that were associated with the aquatic environment were also included as helophytes, but plants associated with the terrestrial environment were excluded from monitoring.

\section{Environmental variables}

Two surface water samples were taken at each location in the urban and semi-natural water systems. The $\mathrm{pH}$ and alkalinity were measured on the following day, after samples had been stored overnight at $4^{\circ} \mathrm{C}$. Total inorganic carbon (TIC) was measured with an $\mathrm{ABB}$ Advance Optima Infrared Gasanalyser, and $\mathrm{CO}_{2}, \mathrm{HCO}_{3}{ }^{-}$and $\mathrm{CO}_{3}{ }^{2-}$ were calculated from TIC, $\mathrm{pH}$, and temperature. Water samples were stored at $-20^{\circ} \mathrm{C}$ until further analysis, after adding citric acid $\left(125 \mathrm{mg} \mathrm{L}^{-1}\right)$. The following ions were measured colorimetrically (Auto Analyzer 3, Digital colorimeter, Bran + Luebbe, Germany): $\mathrm{NO}_{3}{ }^{-}$according to Kamphake et al. (1967), $\mathrm{NH}_{4}{ }^{+}$according to Grasshoff and Johannsen (1972), $\mathrm{Cl}^{-}$according to O'Brien (1962) and $\mathrm{PO}_{4}{ }^{3-}$ according to Henriksen (1965). $\mathrm{Na}^{+}$and $\mathrm{K}^{+}$ were measured photometrically with a flame photometer (Radiometer, Copenhagen). Metals, Total-S, Total-P, $\mathrm{Ca}^{2+}$ and $\mathrm{Mg}^{2+}$ were measured by inductively coupled plasma mass spectrometry (Thermo Electron Corporation, United Kingdom). All physico-chemical factors were measured at least in duplicate and average values were used for data analysis. Altitude was determined using an interactive altitude map (http://www.ahn.nl).

Data analysis

Canoco for Windows Version 4.0 (Ter Braak and Šmilauer 1998) was used to perform Canonical correspondence analysis (CCA) in order to relate macrophyte assemblages in urban and semi-natural water systems to environmental variables. Rural waters were not included in CCA, because data on environmental variables of these waters was not available. CCA is a direct ordination method incorporating linear correlations and regressions between species data and environmental variables. The ordination axes are a result from the joint variation in species and environmental data (Jongman et al. 1995). A unimodal response model was selected, because there was a wide range in environmental variables. Environmental variables with log-normal distributions $\left(\mathrm{NH}_{4}{ }^{+}\right.$, total $\mathrm{Fe}$ and $\left.\mathrm{Al}^{3+}\right)$ were log-transformed. Significance of environmental variables was tested with CCA, using 500 Monte Carlo permutations under full model conditions.
Differences of environmental variables between urban and semi-natural water systems were tested with a MannWhitney test. Species composition of urban and seminatural water systems was also compared with artificial water bodies in rural areas. In the national database of the water boards (STOWA 2008) 36 locations were selected within a $500 \mathrm{~km}^{2}$ area around Arnhem and Nijmegen and macrophyte species composition and abundance were determined.

Total macrophyte diversity in urban and semi-natural water systems was compared with macrophyte diversity in artificial water bodies in rural areas (STOWA 2008). A power function was used to relate number of species $(S)$ with rural area $(A)$.

$S=\mathrm{c} A^{z}$

where $\mathrm{c}$ is a constant and $z$ the scaling exponent (Preston 1960; MacArthur and Wilson 1967; Rosenzweig 1995).

The number of macrophyte species in the rural area was calculated for eight concentric squares with Arnhem and Nijmegen as the centre, with an increasing area of 250 , 500, 975, 2,285, 4,416, 8,680, 12,698 and 17,841 $\mathrm{km}^{2}$ (Fig. 1a). These areas included both terrestrial and wet areas, but Belgium and Germany were excluded from these surface areas. A linear regression was fitted to log-transformed species number and area data. From the linear regression, the expected number of species was calculated for the urban and semi-natural area, with $95 \%$ confidence limits. The surface area of the urban and semi-natural area was calculated by drawing a square around all urban water systems and semi-natural water systems (total urban area: $273 \mathrm{~km}^{2}$, total semi-natural area $7.5 \mathrm{~km}^{2}$, Fig. 1a).

Additionally, average macrophyte species richness was compared between the 45 urban water systems, eight seminatural water systems and 36 artificial water bodies in rural areas within $500 \mathrm{~km}^{2}$ around Arnhem and Nijmegen with a Mann-Whitney test $(P<0.05)$.

For each species, the minimum distance was calculated to the location closest to the study areas where the species was found in artificial water bodies in rural areas (STOWA 2008; Fig. 2). The minimum distances of species present and absent in the study area were compared with a MannWhitney test $(P<0.05)$.

\section{Results}

Species composition and local environmental factors

Canonical correspondence analysis (CCA) clearly separated helophyte assemblages of semi-natural water systems from urban water systems (Fig. 3a). The pH, alkalinity, $\mathrm{CO}_{2}$, altitude, $\mathrm{NO}_{3}{ }^{-}$, total-Fe and $\mathrm{Zn}^{2+}$ concentrations were 


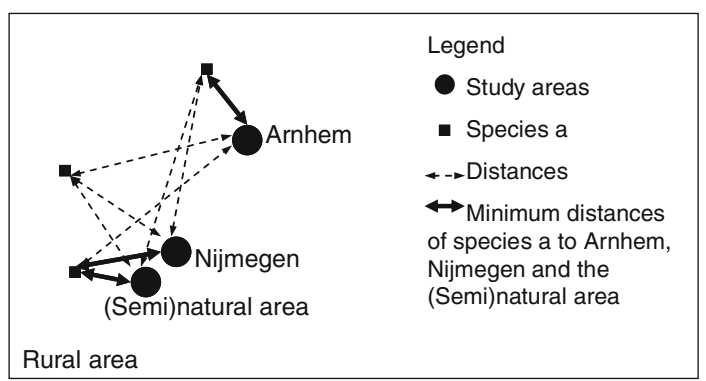

Fig. 2 Schematic overview of the calculation of minimum distances

significantly correlated to variation in helophyte assemblages. The distinction of urban and semi-natural water systems was less clear for hydrophyte assemblages according to CCA (Fig. 3b). The $\mathrm{pH}, \mathrm{Mg}^{2+}, \mathrm{Na}^{+}$and total-Fe were significantly related to variation in hydrophyte assemblages.

Nutrient concentrations $\left(\mathrm{NO}_{3}{ }^{-}, \mathrm{PO}_{4}{ }^{3-}\right.$, total-S) were significantly higher in urban water systems than in seminatural water systems (Table 1). The $\mathrm{pH}$, alkalinity, $\mathrm{HCO}_{3}{ }^{-}$and $\mathrm{Ca}^{2+}$ were also significantly higher in urban water systems, while total-Fe and $\mathrm{Al}^{3+}$ concentrations were significantly higher in semi-natural water systems. $\mathrm{Zn}^{2+}$ concentrations were highest in urban water systems. On average semi-natural water systems were located at significantly higher altitude than urban water systems.

Epilobium hirsutum, Persicaria amphibia, Lythrum salicaria, Ceratophyllum demersum and Hydrocharis morsusranae were abundant in urban artificial water systems and rural areas, but absent in semi-natural water systems (Table 2). Lotus pendunculatus, Carex acuta, Galium palustre and Lysimachia vulgaris were most abundant in urban and semi-natural water systems. The following species were found exclusively in semi-natural water systems: Pilularia globulifera, Potentilla palustris, Ranunculus repens, Sphagnum fallax, Carex rostrata, Ranunculus flammula, Cardamine pratensis, Agrostis stolonifera, Potamogeton natans and Potamogeton polygonifolius. However, Ranunculus repens, Cardamine pratensis and Agrostis stolonifera can also occur in grasslands around urban waters.

The exotic species Hydrocotyle ranunculoides, Ludwigia grandiflora, Pontederia cordata and Lemna minuta appeared exclusively in urban water systems (Table 2), while Azolla filiculoides was only present in artificial water bodies in rural areas. Each exotic species was found in $<7 \%$ of the sampling locations, with the exception of Lemna minuta, which was present in $47 \%$ of the sampling locations in the urban area.

Macrophyte species diversity and species pool limitations

Log-transformed numbers of helophyte and hydrophyte species were linearly correlated to the log-transformed area
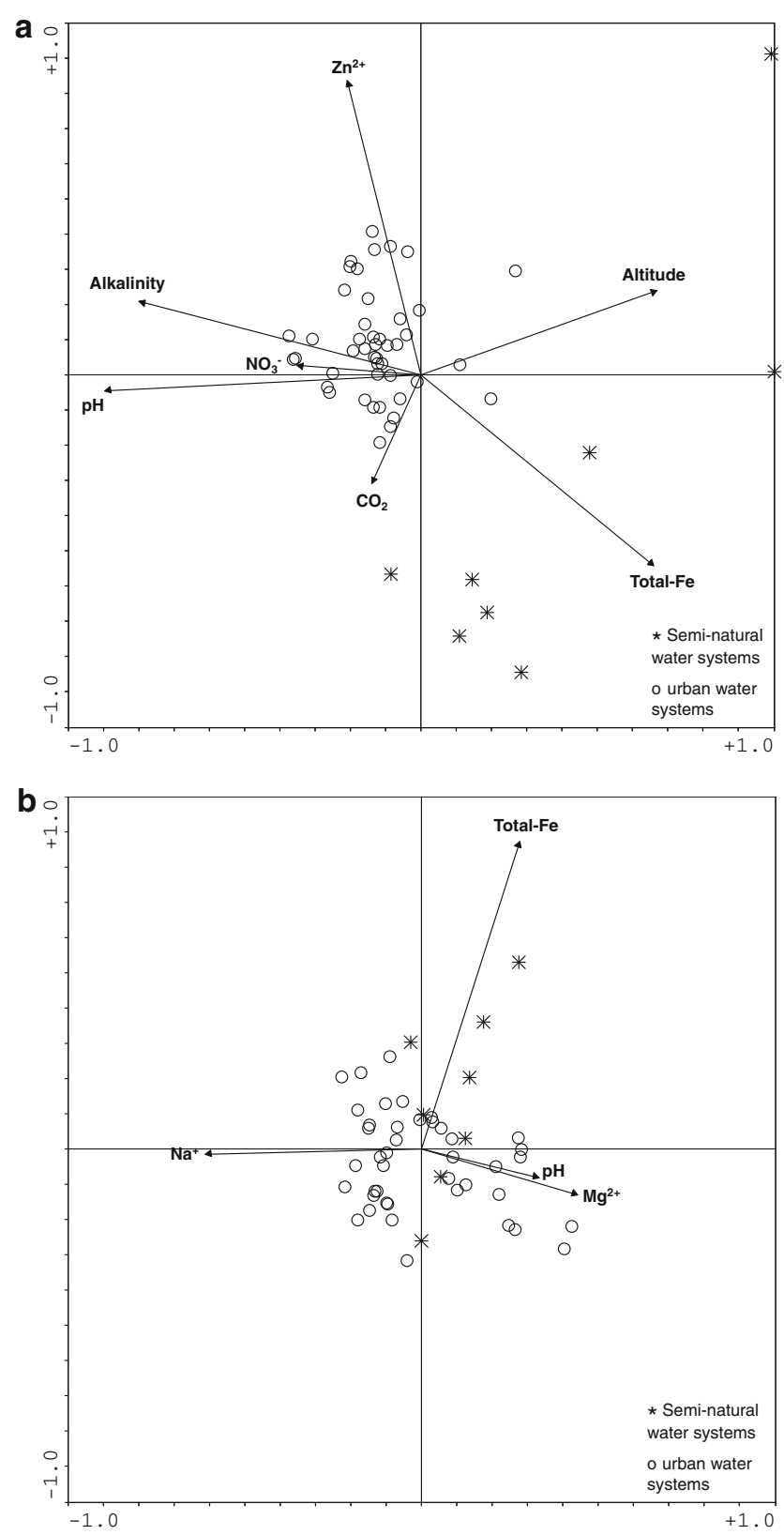

Fig. 3 Canonical correspondence analysis of helophyte (a) and hydrophyte (b) species in semi-natural water systems and urban water systems. Circles and stars represent locations, while arrows represent environmental variables explaining a significant proportion of variation in helophyte and hydrophyte assemblages between locations

of the rural environment $\left(P<0.05, R^{2}=0.97-0.99\right.$, Fig. 4). In the semi-natural area, the number of helophyte species exceeded the number of species expected from linear species-area regressions of rural areas (Fig. 4). The number of hydrophyte species was within the expected 95\% confidence interval. The number of helophyte and hydrophyte species in urban areas exceeded the expected number of species, but the value for hydrophyte species 
Table 1 Average values of environmental variables (minimum and maximum values in brackets)

\begin{tabular}{|c|c|c|}
\hline & Urban $(n=45)$ & Semi-natural $(n=8)$ \\
\hline $\mathrm{NO}_{3}^{-}\left(\mu \mathrm{mol} \mathrm{L}{ }^{-1}\right)$ & $64(1-446)$ & $16(0-76)$ \\
\hline $\mathrm{NH}_{4}^{+}\left(\mu \mathrm{mol} \mathrm{L}{ }^{-1}\right)$ & $85(1-4,544)$ & $9(0-851)$ \\
\hline $\mathrm{PO}_{4}^{3-}\left(\mu \mathrm{mol} \mathrm{L}^{-1}\right)$ & $1.5(0.1-5.9)$ & $0.4(0.1-0.9)$ \\
\hline Total-P $\left(\mu \mathrm{mol} \mathrm{L}{ }^{-1}\right)$ & $1.5(0.3-5.9)$ & $1.2(0.3-2.8)$ \\
\hline Total-S $\left(\mu \mathrm{mol} \mathrm{L} \mathbf{L}^{-1}\right)$ & $441(17-626)$ & $283(12-474)$ \\
\hline $\mathbf{K}^{+}\left(\mu \mathrm{mol} \mathrm{L}{ }^{-1}\right)$ & $102(15-236)$ & $64(17-150)$ \\
\hline $\mathrm{Na}^{+}\left(\mu \mathrm{mol} \mathrm{L}{ }^{-1}\right)$ & $1,157(63-1,811)$ & $737(210-1,638)$ \\
\hline $\mathrm{Cl}^{-}\left(\mu \mathrm{mol} \mathrm{L}{ }^{-1}\right)$ & $1,125(109-1,674)$ & $848(111-1,938)$ \\
\hline pH & $7.3(6.6-8.0)$ & $6.5(5.1-7.8)$ \\
\hline Alkalinity $\left(\operatorname{meq} \mathbf{L}^{-1}\right)$ & $2.91(1.40-4.55)$ & $1.19(0.07-2.07)$ \\
\hline $\mathrm{CO}_{2}\left(\mu \mathrm{mol} \mathrm{L}{ }^{-1}\right)$ & $314(75-697)$ & $297(39-1,034)$ \\
\hline $\mathrm{HCO}_{3}^{-}\left(\mu \mathrm{mol} \mathrm{L}{ }^{-1}\right)$ & $2,474(190-4,548)$ & $1,030(4-2,073)$ \\
\hline $\mathrm{Ca}^{2+}\left(\mu \mathrm{mol} \mathrm{L}{ }^{-1}\right)$ & $1,438(97-2,443)$ & $726(18-1,271)$ \\
\hline $\mathrm{Mg}^{2+}\left(\mu \mathrm{mol} \mathrm{L}{ }^{-1}\right)$ & $331(11-511)$ & $225(17-406)$ \\
\hline Total-Fe $\left(\mu \mathrm{mol} \mathrm{L}{ }^{-1}\right)$ & $1(0-60)$ & $156(19-1,432)$ \\
\hline $\mathrm{Al}^{3+}\left(\mu \mathrm{mol} \mathrm{L} \mathbf{L}^{-1}\right)$ & $0.1(0.0-0.9)$ & $2.3(0.1-7.5)$ \\
\hline $\mathrm{Zn}^{2+}\left(\mu \mathrm{mol} \mathbf{L}^{-1}\right)$ & $0.6(0.3-1.2)$ & $0.2(0.0-1.3)$ \\
\hline Altitude ( $m$ above NAP) & $6.9(5.9-9.8)$ & $8.0(7.1-10.7)$ \\
\hline
\end{tabular}

Significant differences between urban water systems and semi-natural water systems in bold $(P<0.05$, Mann-Whitney test)

was within the expected 95\% confidence interval. Average helophyte species richness was significantly higher in seminatural water systems, than in urban and artificial water systems (Fig. 5). Average hydrophyte species richness was not significantly different between groups.

The minimum distance of macrophyte species present in the study areas was significantly lower than the minimum distance of macrophyte species absent in the study areas (Fig. 6). Helophyte species present in the study areas were generally also found within $30 \mathrm{~km}$ distance to the study area, whereas hydrophyte species that occurred in the study area were found within approximately $20 \mathrm{~km}$ distance of the study areas.

\section{Discussion}

Species composition and site limitation

The CCA of the helophytes distinguished the semi-natural water systems more clearly than that of the hydrophytes (Fig. 3). The pH and iron levels significantly accounted for the variation in both helophyte and hydrophyte composition. Upward seepage of iron-rich groundwater reduced nutrient availability in the semi-natural area and thereby changed species composition (Lucassen et al. 2006). Urban water systems were enriched in nutrients compared to the semi-natural area, which is consistent with other studies (e.g. Paul and Meyer 2001; Walsh et al. 2005). The pH, alkalinity, $\mathrm{HCO}_{3}{ }^{-}$and $\mathrm{Ca}^{2+}$ were significantly lower in the semi-natural water systems than in urban water systems. This could be related to the influence of local groundwater, which introduced acidic water in the semi-natural area with a pH between 3.9 and 5.2 (Lucassen and Smolders 2008). Iron and aluminium diffuse from the sediment at low $\mathrm{pH}$ (Wetzel 2001) in the semi-natural water systems. Higher zinc concentrations in the urban water systems were related to storm-water run-off from impervious areas (Paul and Meyer 2001; Brabec et al. 2002; Vermonden et al. 2009b).

Most species occurred in both urban water systems and artifical water bodies in rural areas (Table 2). Nine species were exclusively present in semi-natural water systems, among which Pilularia globulifera, Potentilla palustris, Sphagnum fallax, Carex rostrata, Ranunculus flammula, and the hydrophytes Potamogeton natans and Potamogeton polygonifolius were typical for slightly acid, oligotrophic waters (De Lyon and Roelofs 1986).

Four out of five exotic species in this study appeared exclusively in urban water systems, the other one was present exclusively in artificial water bodies in rural areas (Table 2). No exotic species were present in the seminatural water systems. Exotic species also appeared exclusively in urban streams in the northern Sydney region, which could be related to higher nutrient levels in urban sediments (King and Buckney 2000). Kercher and Zedler (2004) also suggested that invasive macrophyte species could easily dominate native species where nutrient availability is high. Ehrenfeld (2008) related invasive species specifically to residential areas.

Propagule pressure of exotic species is high in urban areas, because of dispersal from ponds in gardens and parks and human introductions (e.g. by dumping of plant material from aquaria and ponds). Ludwigia grandiflora and Pontederia cordata are sold as garden plants in the Netherlands and Hydrocotyle ranunculoides was sold until 2001. Anthropogenic disturbance, such as vegetation removal, also contributes to plant invasions (Detenbeck et al. 1999). The combined influence of eutrophication, propagule pressure and disturbance make the urban waters vulnerable for species invasions. Besides the exotic species, only Lemna gibba occurred exclusively in the urban water systems. Lemna gibba is associated with eutrophic water (Papastergiadou and Babalonas 1993). The presence of lemnids in the urban water systems can also be associated with stagnant water systems and muddy sediment (Boedeltje et al. 2005). Water systems in the rural and semi-natural area could have higher flow velocities and could therefore be less suitable for the growth of lemnids. 
Table 2 Presence and average abundance of characteristic helophytes and hydrophytes in urban, rural and semi-natural areas

\begin{tabular}{|c|c|c|c|c|c|c|}
\hline \multirow[t]{2}{*}{ Helophytes } & \multicolumn{2}{|c|}{ Urban $(n=45)$} & \multicolumn{2}{|c|}{$\begin{array}{l}\text { Artificial water bodies in rural } \\
\text { area }(n=36)\end{array}$} & \multicolumn{2}{|c|}{$\begin{array}{l}\text { Semi-natural water systems in rural } \\
\text { area }(n=8)\end{array}$} \\
\hline & Presence (\%) & Abundance & Presence $(\%)$ & Abundance & Presence $(\%)$ & Abundance \\
\hline Hydrocotyle ranunculoides (NSA) & 7 & 6 & 0 & 0 & 0 & 0 \\
\hline Ludwigia grandiflora (tropics, SA) & 2 & 3 & 0 & 0 & 0 & 0 \\
\hline Pontederia cordata (NSA) & 2 & 2 & 0 & 0 & 0 & 0 \\
\hline Epilobium hirsutum & 51 & 4 & 34 & 2 & 0 & 0 \\
\hline Persicaria amphibia & 47 & 4 & 37 & 2 & 0 & 0 \\
\hline Lythrum salicaria & 31 & 4 & 11 & 2 & 0 & 0 \\
\hline Mentha aquatica & 24 & 5 & 9 & 4 & 0 & 0 \\
\hline Symphytum officinale & 13 & 3 & 23 & 2 & 0 & 0 \\
\hline Filipendula ulmaria & 9 & 3 & 29 & 2 & 50 & 4 \\
\hline Alisma plantago-aquatica & 2 & 3 & 26 & 2 & 50 & 3 \\
\hline Equisetum fluviatile & 0 & 0 & 14 & 4 & 38 & 4 \\
\hline Lotus pedunculatus & 44 & 4 & 3 & 3 & 38 & 3 \\
\hline Carex acuta & 27 & 7 & 9 & 3 & 50 & 5 \\
\hline Galium palustre & 22 & 4 & 0 & 0 & 63 & 3 \\
\hline Lysimachia vulgaris & 18 & 4 & 0 & 0 & 88 & 3 \\
\hline Eleocharis palustris & 2 & 5 & 6 & 6 & 50 & 5 \\
\hline Juncus articulatus & 4 & 4 & 0 & 0 & 38 & 3 \\
\hline Pilularia globulifera & 0 & 0 & 0 & 0 & 25 & 6 \\
\hline Potentilla palustris & 0 & 0 & 0 & 0 & 25 & 3 \\
\hline Ranunculus repens & 0 & 0 & 0 & 0 & 25 & 2 \\
\hline Sphagnum fallax & 0 & 0 & 0 & 0 & 25 & 4 \\
\hline Carex rostrata & 0 & 0 & 0 & 0 & 38 & 6 \\
\hline Ranunculus flammula & 0 & 0 & 0 & 0 & 50 & 3 \\
\hline Cardamine pratensis & 0 & 0 & 0 & 0 & 63 & 2 \\
\hline Agrostis stolonifera & 0 & 0 & 0 & 0 & 75 & 6 \\
\hline \multicolumn{7}{|l|}{ Hydrophytes } \\
\hline Lemna minuta (NA) & 47 & 6 & 0 & 0 & 0 & 0 \\
\hline Lemna gibba & 7 & 3 & 0 & 0 & 0 & 0 \\
\hline Ceratophyllum demersum & 27 & 5 & 16 & 2 & 0 & 0 \\
\hline Hydrocharis morsus-ranae & 11 & 5 & 19 & 4 & 0 & 0 \\
\hline Spirodela polyrhiza & 11 & 2 & 47 & 3 & 0 & 0 \\
\hline Enteromorpha sp. & 9 & 3 & 13 & 3 & 0 & 0 \\
\hline Nuphar lutea & 4 & 8 & 16 & 4 & 0 & 0 \\
\hline Azolla filiculoides (NA) & 0 & 0 & 3 & 2 & 0 & 0 \\
\hline Fontinalis antipyretica & 0 & 0 & 9 & 2 & 0 & 0 \\
\hline Sparganium emersum & 4 & 4 & 6 & 5 & 25 & 2 \\
\hline Lemna trisulca & 9 & 4 & 19 & 2 & 38 & 4 \\
\hline Potamogeton natans & 0 & 0 & 0 & 0 & 38 & 4 \\
\hline Potamogeton polygonifolius & 0 & 0 & 0 & 0 & 13 & 7 \\
\hline
\end{tabular}

Presence is expressed as percentage of locations where a species occurred and abundance on Tansley scale (0-9). Exotic species in bold, defined according to Van der Velde et al. (2002); native area between brackets: NSA North/South America, NA North America, SA South America 

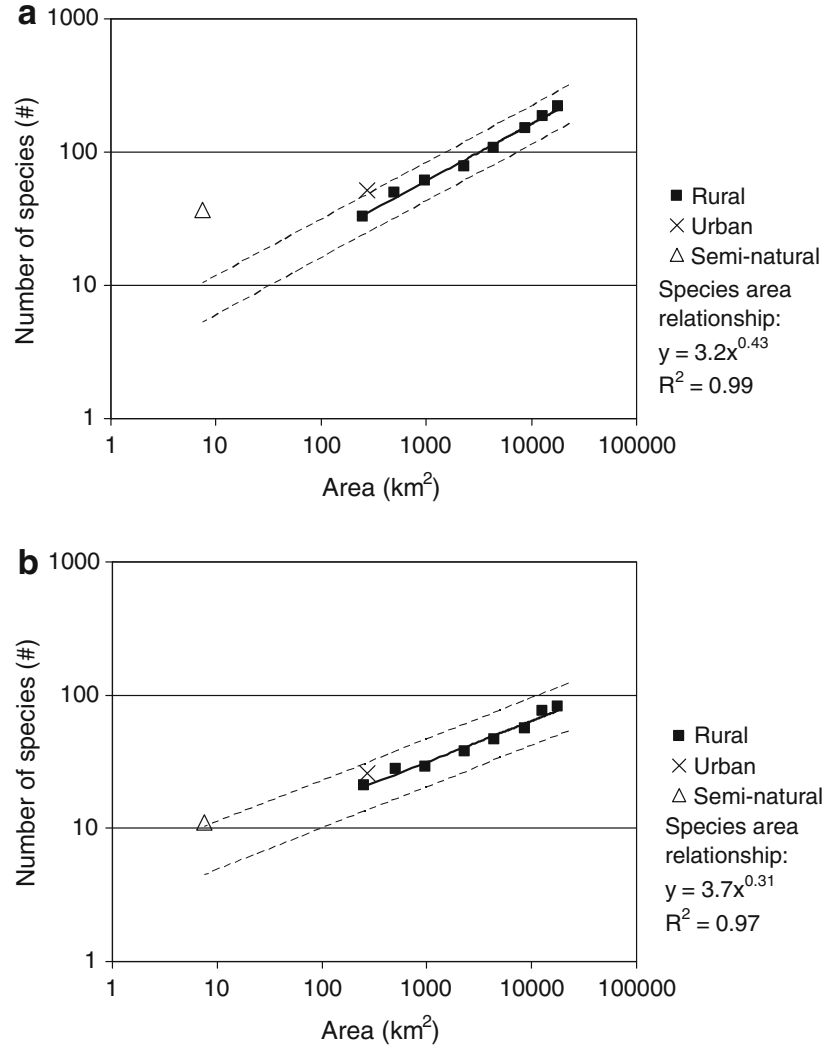

Fig. 4 Relationship between number of helophyte (a) and hydrophyte (b) species and surface areas. Dotted lines indicate confidence intervals of species-area relationship in rural areas (STOWA 2008)

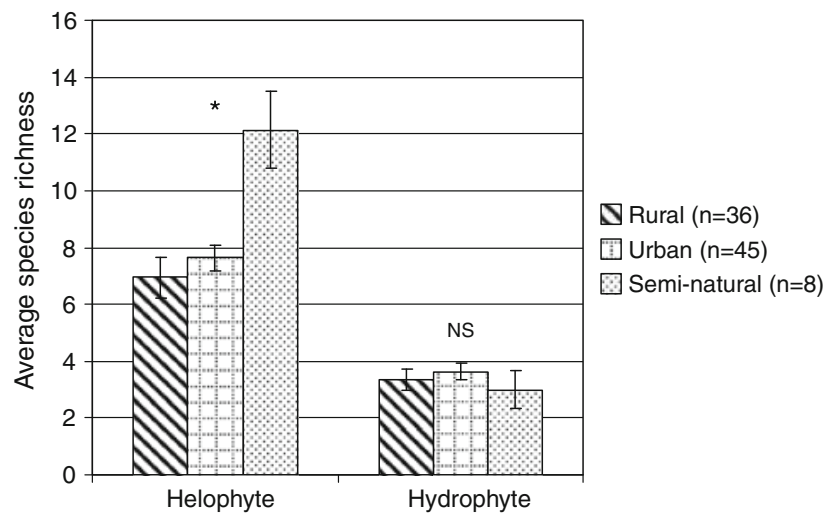

Fig. 5 Average species richness in urban, rural and semi-natural water systems. Significant difference is indicated with an asterisk (Mann-Whitney test, $P<0.05$ )

Macrophyte species diversity

Although dredging and mowing can reduce macrophyte species richness temporarily, the local species pool was probably unaffected because all water systems were interconnected and species could disperse very quickly through the systems. Moreover, mowing and dredging activities were mainly performed in the middle of the ditches to
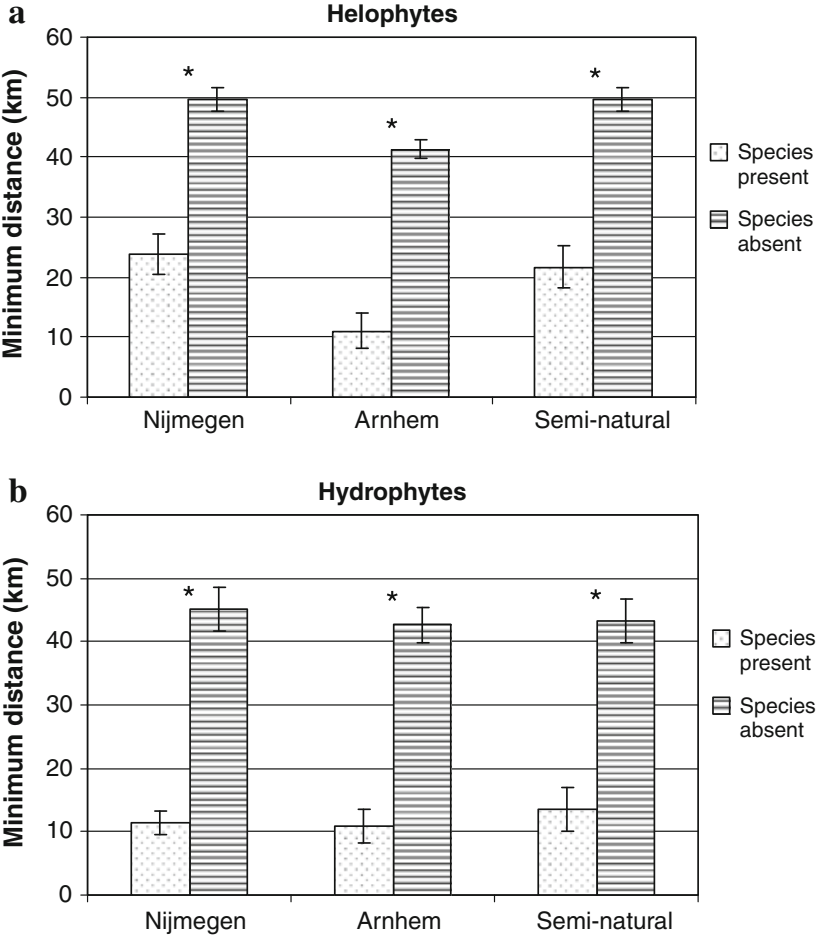

Fig. 6 Average distances to nearest location where helophyte (a) and hydrophyte (b) species were found in the national database (STOWA 2008). Averages calculated for species present and absent in the urban water systems of Nijmegen, Arnhem and semi-natural water systems. Significant differences are indicated with an asterisk (Mann-Whitney test, $P<0.05$ )

guarantee discharge capacity, and vegetation near the banks was partly left intact according to nature-oriented mowing and dredging schemes.

Log-transformed numbers of helophyte and hydrophyte species in artificial water bodies in rural areas were strongly correlated to log-transformed area (Fig. 4, $R^{2}=0.99$ and 0.97 , respectively). The slope of speciesarea relationships $(z)$ depends on the scale, habitat diversity and taxonomic groups included in the analysis (Wright 1981; Rosenzweig 1995; Ricklefs and Lovette 1999; Crawley and Harral 2001; Koh et al. 2002; Turner and Tjørve 2005; Drakare et al. 2006; Kallimanis et al. 2008). Crawley and Harral (2001) showed that $z$ values for plants were in the range of $0.1-0.2$ at small scales $\left(<100 \mathrm{~m}^{2}\right)$, $0.4-0.6$ at intermediate scales $\left(10,000 \mathrm{~m}^{2}-10 \mathrm{~km}^{2}\right)$ and $0.1-0.4$ at the largest scale $\left(10-1,000 \mathrm{~km}^{2}\right)$. Our speciesarea relationships had $z$-values of 0.43 (helophytes) and 0.31 (hydrophytes) at scales of $250-17,841 \mathrm{~km}^{2}$. Slopes are at the upper end of the range noted by Crawley and Harral (2001).

Species-area relationships of different taxonomic groups also result in different slopes, as was shown for very different groups such as plants, springtails, butterflies, reptiles, amphibians, mammals and birds (Wright 1981; 
Ricklefs and Lovette 1999; Koh et al. 2002). Koh et al. (2002) found that species with higher dispersal ability were related to lower $z$-values because they were less sensitive to the area effect than species with low dispersal ability. Our study showed that even within highly related groups such as helophytes and hydrophytes, there can be differences in species-area relationships. Ricklefs and Lovette (1999) suggested that habitat specialization would make species richness more sensitive to habitat diversity and less sensitive to area.

The number of helophyte species is somewhat (urban) and substantially larger (semi-natural) in comparison to the richness-area regression for rural regions. By contrast, hydrophyte richness is within (urban) and just above (seminatural) the 95\%-confidence interval noted for rural areas. Comparisons of average species richness agreed with these results. Hydrophytes show broad distribution ranges and limited taxonomic differentiation because they have to be adapted to a stressful environment, characterised by low carbon availability, shaded conditions, sediment anoxia and wave exposure (Santamaría 2002). This explains why we found fewer hydrophyte species than helophyte species and less differentiation between habitat types. This could be an additional explanation why $z$ values in species-area relationships are lower for hydrophytes than for helophytes. Next to that, hydrophytes might be influenced more by eutrophication of water bodies than helophytes.

Average helophyte species richness per site was significantly higher in semi-natural water systems than in urban and rural waters (Fig. 5). Artificial water systems in urban and rural areas sustain fewer species because these water systems are eutrophic and often disturbed. Other studies also document a decrease in macrophyte species richness with increased disturbance and associated eutrophication (Riis and Sand-Jensen 2001; Egertson et al. 2004; Lougheed et al. 2008).

Some studies showed that the size of individual water systems is positively related to species richness (e.g. Barbour and Brown 1974; Dodson 1992). Other studies did not show a significant relationship between aquatic plant diversity and lake size, especially in temperate, small to medium-sized lakes (e.g. Declerck et al. 2005; Kruk et al. 2009). In our study, the species richness of macrophytes were not significantly related to the size of the individual ditches and ponds. On average, the sizes of water systems in urban, rural and semi-natural water systems were very similar and individual water systems were also interconnected. The size of individual water systems was therefore considered to be a minor factor affecting macrophyte species richness in our study area.
Species pool versus site limitation

Species present in the urban and semi-natural area were also present within relatively short distances in the regional species pool of artificial water bodies in rural areas (Fig. 6). Helophyte species were, on average, found between 5 and $30 \mathrm{~km}$ from the monitored sites and hydrophyte species were found between 5 and $20 \mathrm{~km}$ from the monitored sites. In contrast, the nearest growing site of species that were not recorded in our surveys was, on average, more than $40 \mathrm{~km}$ away. This could imply that the local species pool may be limited by the regional species pool, corresponding with the species pool hypothesis $(\mathrm{Ca}-$ ley and Schluter 1997; Zobel 1997; Partel and Zobel 1999). Abiotic conditions might also be more similar within a short distance and therefore result in a more similar species composition.

Macrophyte species composition and diversity were also strongly dependent on local abiotic processes (Figs. 3, 5). The available data did not allow quantification of variation in species composition attributable to site characteristics versus the regional species pool. Quantification of this variation may be possible with additional multivariate analysis, but will require data on species pools of individual sites. Large-scale processes such as dispersal determine how many and which species are available for the local community (Zobel 1997). Our study shows that the actual local species composition in urban water systems and semi-natural water systems was determined by the ability of species to cope with local biotic and abiotic circumstances.

\section{Conclusions}

Macrophyte species composition in urban and semi-natural water systems differed and could be related to local abiotic variables, such as $\mathrm{pH}$ and iron concentrations. In urban water systems, exotic species typical of eutrophic conditions were present. In semi-natural water systems, exotic species were absent and indicators for slightly acidic and oligotrophic conditions were present. Macrophyte species composition in the urban water systems and semi-natural water systems also appeared to be influenced by the regional species pool located within approximately $30 \mathrm{~km}$ of the sites. Nevertheless, site limitation eventually determined the local macrophyte composition and diversity in urban water systems and semi-natural water systems. This is illustrated by the higher species richness in the semi-natural water systems in the immediate vicinity of the urban areas. 
Acknowledgments We thank Kim Lotterman for performing the vegetation monitoring in urban water systems, Jelle Eygensteyn for assistance in the laboratory and two anonymous reviewers for their comments. We thank Ton Verhoeven (Municipality of Nijmegen), Henk Velthorst, Hans van Ammers (Municipality of Arnhem) and Harriët de Ruiter (Waterboard Rivierenland) for stimulating discussions on urban water systems. The project was financially supported by the Interreg IIIb North-West Europe Urban water program, the municipalities of Nijmegen and Arnhem, and Radboud University Nijmegen.

Open Access This article is distributed under the terms of the Creative Commons Attribution Noncommercial License which permits any noncommercial use, distribution, and reproduction in any medium, provided the original author(s) and source are credited.

\section{References}

Antoine C, Castella E, Castella-Müller J, Lachavanne J-B (2004) Habitat requirements of freshwater gastropod assemblages in a lake fringe wetland (Lake Neuchâtel, Switzerland). Arch Hydrobiol 159:377-394

Barbour CD, Brown JH (1974) Fish species diversity in lakes. Am Nat 108:473-489

Boedeltje G, Smolders AJP, Lamers LPM, Roelofs JGM (2005) Interactions between sediment propagule banks and sediment nutrient fluxes explain floating plant dominance in stagnant shallow waters. Arch Hydrobiol 162:349-362

Booth DB (2005) Challenges and prospects for restoring urban streams: a perspective from the Pacific Northwest of North America. J North Am Benthol Soc 24:724-737

Brabec E, Schulte S, Richards PL (2002) Impervious surfaces and water quality: a review of current literature and its implications for watershed planning. J Plan Lit 16:499-514

Caley MJ, Schluter D (1997) The relationship between local and regional diversity. Ecology 78:70-80

Cheruvelil KS, Soranno PA (2008) Relationships between lake macrophyte cover and lake and landscape features. Aquat Bot 88:219-227

Collinge SK (1996) Ecological consequences of habitat fragmentation: implications for landscape architecture and planning. Landsc Urban Plan 36:59-77

Cornell HV, Lawton JH (1992) Species interactions, local and regional processes, and limits to the richness of ecological communities: a theoretical perspective. J Anim Ecol 61:1-12

Crawley MJ, Harral JE (2001) Scale dependence in plant biodiversity. Science 291:864-868

De Lyon MJH, Roelofs JGM (1986) Waterplanten in relatie tot waterkwaliteit en bodemgesteldheid. Laboratorium voor Aquatische Oecologie, Katholieke Universiteit, Nijmegen

Declerck S, Vandekerkhove J, Johansson L, Muylaert K, CondePorcuna JM, Van der Gucht K, Pérez-Martínez C, Lauridsen T, Schwenk K, Zwart G, Rommens W, López-Ramos J, Jeppesen E, Vyverman W, Brendonck L, De Meester L (2005) Multi-group biodiversity in shallow lakes along gradients of phosphorus and water plant cover. Ecology 86:1905-1915

Detenbeck NE, Galatowitsch SM, Atkinson J, Ball H (1999) Evaluating perturbations and developing strategies for inland wetlands in the Great Lakes Basin. Wetlands 19:789-820

Dodson S (1992) Predicting zooplankton species richness. Limnol Oceanogr 37:848-856

Drakare S, Lennon JJ, Hillebrand H (2006) The imprint of the geographical, evolutionary and ecological context on speciesarea relationships. Ecol Lett 9:215-227
Drayton B, Primack RB (1996) Plant species lost in an isolated conservation area in metropolitan Boston from 1894 to 1993. Conserv Biol 10:30-39

Egertson CJ, Kopaska JA, Downing JA (2004) A century of change in macrophyte abundance and composition in response to agricultural eutrophication. Hydrobiologia 524:145-156

Ehrenfeld JG (2008) Exotic invasive species in urban wetlands: environmental correlates and implications for wetland management. J Appl Ecol 45:1160-1169

Evans FC, Clark PJ, Brand RH (1955) Estimation of the number of species present on a given area. Ecology 36:342-343

Grasshoff K, Johannsen H (1972) A new sensitive and direct method for the automatic determination of ammonia in sea water. $\mathrm{J}$ Conseil 34:516-521

Hamilton AM, Hartman JH, Austin CC (2009) Island area and species diversity in the southwest Pacific Ocean: is the lizard fauna of Vanuatu depauperate? Ecography 32:247-258

He F, Legendre P (1996) On species-area relations. Am Nat 148:719_ 737

Henriksen A (1965) An automatic method for determining low-level concentrations of phosphates in fresh and saline waters. Analyst 90:29-34

Jongman RHG, Ter Braak CJF, Van Tongeren OFR (1995) Data analysis in community and landscape ecology. Cambridge University Press, Cambridge

Kallimanis AS, Mazaris AD, Tzanopoulos J, Halley JM, Pantis JD, Sgardelis SP (2008) How does habitat diversity affect the species-area relationship? Glob Ecol Biogeogr 17:532-538

Kamphake LJ, Hannah SA, Cohen JM (1967) Automated analysis for nitrate by hydrazine reduction. Water Res 1:205-216

Kercher SM, Zedler JB (2004) Flood tolerance in wetland angiosperms: a comparison of invasive and noninvasive species. Aquat Bot 80:89-102

King SA, Buckney RT (2000) Urbanization and exotic plants in northern Sydney streams. Austral Ecol 25:455-461

Koh LP, Sodhi NS, Tan HTW, Peh KSH (2002) Factors affecting the distribution of vascular plants, springtails, butterflies and birds on small tropical islands. J Biogeogr 29:93-108

Kruk C, Rodrígues-Gallego L, Meerhoff M, Quintas F, Lacerot G, Mazzeo N, Scasso F, Paggi JC, Peeters ETHM, Scheffer M (2009) Determinants of biodiversity in subtropical shallow lakes (Atlantic coast, Uruguay). Freshw Biol 54:2628-2641

Larson MG, Booth DB, Morley SA (2001) Effectiveness of large woody debris in stream rehabilitation projects in urban basins. Ecol Eng 18:211-226

Lougheed VL, McIntosh MD, Parker CA, Stevenson RJ (2008) Wetland degradation leads to homogenization of the biota at local and landscape scales. Freshw Biol 53:2402-2413

Lucassen ECHET, Smolders AJP (2008) Mogelijkheden tot herstel van natuurwaarden in de gebieden Hatertse \& Overasseltse vennen en het Wijchense ven; kwaliteit van oppervlaktewater, grondwater en bodemwater. Report no 2008.025, B-WARE Research Centre, Nijmegen

Lucassen ECHET, Smolders AJP, Boedeltje G, Van den Munckhof PJJ, Roelofs JGM (2006) Groundwater input affecting plant distribution by controlling ammonium and iron availability. J Veg Sci 17:425-434

MacArthur RH, Wilson EO (1967) The theory of island biogeography. Princeton University Press, Princeton

McKinney ML (2005) Urbanization as a major cause of biotic homogenization. Biol Conserv 127:247-260

O'Brien JE (1962) Automation in sanitary chemistry, Part 4: automatic analysis of chlorides in sewage. Wastes Eng $33: 670-672$

Papastergiadou E, Babalonas D (1993) The relationship between hydrochemical environmental-factors and the aquatic 
macrophyte vegetation in stagnant and slow-flowing water. 1 . Water quality and distribution of aquatic associations. Arch Hydrobiol 4(Suppl 90):475-491

Partel M, Zobel M (1999) Small-scale plant species richness in calcareous grasslands determined by the species pool community age and shoot density. Ecography 22:153-159

Paul MJ, Meyer JL (2001) Streams in the urban landscape. Annu Rev Ecol Syst 32:333-365

Preston FW (1960) Time and space and the variation of species. Ecology 41:612-627

Ranta P, Toivonen H (2008) Changes in aquatic macrophytes since 1933 in an urban lake, Lidesjarvi, SW Finland. Ann Bot Fenn 45:359-371

Ricklefs RE (2004) A comprehensive framework for global patterns in biodiversity. Ecol Lett 7:1-15

Ricklefs RE, Lovette IJ (1999) The roles of island area per se and habitat diversity in the species-area relationship of four Lesser Antillean faunal groups. J Anim Ecol 68:1142-1160

Riis T, Sand-Jensen K (2001) Historical changes in species composition and richness accompanying perturbation and eutrophication of Danish lowland streams over 100 years. Freshw Biol 46:269-280

Rosenzweig ML (1995) Species diversity in space and time. Cambridge University Press, Cambridge

Santamaría L (2002) Why are most aquatic plants widely distributed? Dispersal, clonal growth and small-scale heterogeneity in a stressful environment. Acta Oecologia 23:137-154

Statistics Netherlands (2009) Statline. http://statline.cbs.n1/statweb/ accessed 14 Sep 2009

STOWA (2008) Limnodata Neerlandica 2000-2006. http://www. limnodata.nl accessed 10 Aug 2008

Suren AM, McMurtrie S (2005) Assessing the effectiveness of enhancement activities in urban streams: II. Responses of invertebrate communities. River Res Appl 21:439-453

Tansley AG (1946) Introduction to plant ecology. A guide for beginners in the study of plant communities. Allen \& Unwin, London
Ter Braak CJF, Šmilauer P (1998) CANOCO Reference manual and user's guide to Canoco for Windows: software for canonical community ordination (version 4). Microcomputer Power, Ithaca, New York

Turner WR, Tjørve E (2005) Scale-dependence in species-area relationships. Ecography 28:721-730

Van der Velde G, Nagelkerken I, Rajagopal S, Bij de Vaate A (2002) Invasions by alien species in inland freshwater bodies in western Europe: the Rhine delta. In: Leppäkoski E, Gollasch S, Olenin S (eds) Invasive aquatic species of Europe. Distribution, impacts and management. Kluwer Academic Publishers, Dordrecht, pp $360-372$

Vermonden K, Leuven RSEW, Van der Velde G, Van Katwijk MM, Roelofs JGM, Hendriks AJ (2009a) Urban drainage systems: an undervalued habitat for aquatic macroinvertebrates. Biol Conserv 142:1105-1115

Vermonden K, Hermus MAA, Van Weperen M, Leuven RSEW, Van der Velde G, Smolders AJP, Roelofs JGM, Hendriks AJ (2009b) Does upward seepage of river water and storm water runoff determine water quality of urban drainage systems in lowland areas? A case study for the Rhine-Meuse delta. Hydrol Process 23:3110-3120

Walsh CJ, Roy AH, Feminella JW, Cottingham PD, Groffman PM, Morgan RP (2005) The urban stream syndrome: current knowledge and the search for a cure. J N Am Benthol Soc 24:706-723

Wetzel RG (2001) Limnology: lake and river ecosystems, 3rd edn. Academic Press, San Diego

Wright SJ (1981) Intra-archipelago vertebrate distributions: the slope of the species-area relation. Am Nat 118:726-748

Zobel M (1997) The relative role of species pools in determining plant species richness: an alternative explanation of species coexistence? Trends Ecol Evol 12:266-269 